\title{
Potentially harmful materials in the feces of wild ring-tailed coatis (Nasua nasua) and health implications
}

\author{
Delma Henriques Domiciano Rodrigues ${ }^{1}$ (iD) Vanner Boere ${ }^{1,2^{*}}$ (iD) Clarice Silva Cesario ${ }^{3}$ \\ Waldomiro de Paula Lopes $^{4}$ (D) Alexandre Bartoli Monteiro ${ }^{5}$ (ID) Ita Oliveira Silva ${ }^{1,2}$
}

'Programa de Pós-graduação em Biologia Animal, Universidade Federal de Viçosa (UFV), Viçosa, MG, Brasil.

${ }^{2}$ Universidade Federal do Sul da Bahia (UFSB), 45613-204, Itabuna, BA, Brasil. E-mail: vannerboere@uol.com.br. "Correspondent author. ${ }^{3}$ Universidade de São Paulo (USP), São Paulo, SP, Brasil.

${ }^{4}$ Instituto Chico Mendes de Biodiversidade (ICMBio), PNC, Alto Caparaó, MG, Brasil.

${ }^{5}$ Instituto Federal do Sudeste de Minas Gerais, Barbacena, MG, Brasil.

\begin{abstract}
In ecological parks, the proximity to tourist activities facilitates the exploration of garbage by coatis, with possible serious consequences for the animals health. We described the contents of wild coatis feces from three ecological parks. After analyzing 62 samples, fragments of plants and animals were identified in all feces. In the feces of two parks, seeds were present between $36.4 \%$ and $48.6 \%$ of the samples. Arthropod fragments were identified in $100 \%$ of the samples from two parks, but only $87.3 \%$ in a third park. Scales, bones or bird feathers were present in some samples. Undigested material of industrial origin was detected in $34.3 \%$ to $54.5 \%$ of the samples, such as fragments of paper, string, plastic, aluminum, latex and glass. Results are in line with other studies on the diet of wild coatis, but the intake of foreign bodies, potentially harmful to health, is described for the first time. Clinical problems resulting from ingesting waste can be dental fractures, mucosal erosions, intestinal perforation, peritonitis, impaction, diarrhea, weight loss, intoxication and infections. Coatis in the three parks are at risk of health, and actions are needed to avoid clinical and potentially fatal problems. Four actions are recommended to avoid ingesting foreign bodies: increasing the environmental education of visitors; improving the storage of waste generated in parks; periodically monitor the health of coatis, in order to make interventions when possible; make a permanent program to study the ecology of species in the three parks.
\end{abstract}

Key words: animal health, conservation medicine, wildlife.

Materiais potencialmente nocivos encontrados nas fezes de quatis (Nasua nasua) selvagens e implicações para a saúde

RESUMO: Em parques ecológicos, a proximidade com atividades turísticas facilita a exploração do lixo por quatis (Nasua nasua), com possiveis consequências graves para saúde dos animais. Descrevemos o conteúdo de fezes de quatis selvagens de três parques ecológicos. Após análise de 62 amostras, fragmentos de plantas e animais foram identificados em todas as fezes. Nas fezes de dois parques, as sementes estiveram presentes entre 36,4\% e 48,6\% das amostras. Foram identificados fragmentos de artrópodes em 100\% das amostras de dois parques, mas apenas $87,3 \%$ em um terceiro parque. Escamas, ossos ou penas de pássaros estavam presentes em algumas amostras. Detectou-se material não digerido de origem industrial em $34,3 \%$ a $54,5 \%$ das amostras, como fragmentos de papel, barbante, plástico, alumínio, látex e vidro. Os resultados estão de acordo com outros estudos sobre a dieta de quatis selvagens, mas a ingestão de corpos estranhos, potencialmente prejudicial à saúde, é descrito pela primeira vez. Os problemas clínicos decorrentes da ingestão de lixo podem ser fraturas dentais, erosões de mucosas, perfuração intestinal, peritonite, impactação, diarreia, emagrecimento, intoxicação e infecções. Os quatis nos três parques estão com a saúde em risco, sendo necessárias ações para evitar problemas clínicos e potencialmente fatais. Quatro ações são recomendadas para evitar a ingestão de corpos estranhos: aumentar a educação ambiental dos visitantes; melhorar o armazenamento dos resíduos gerados nos parques; monitorar periodicamente a saúde dos quatis, de forma a fazer intervenções quando possível; fazer um programa permanente de estudo da ecologia das espécies nos três parques.

Palavras-chave: medicina da conservação, saúde animal, vida selvagem.

\section{INTRODUCTION}

The coati (Nasua nasua) is a mammal belonging to the Carnivora order and the Procyonidae family, distributed across South America and found in Colombia, Venezuela, Guyana, Suriname, Peru, Bolivia, Argentina, Uruguay, Paraguay, and
Brazil (GOMPPER, DECKER 1998). Although, its abundance varies, it has already been recorded in six biomes in Brazil: the Amazon, the Caatinga, the Cerrado, the Pantanal, the Atlantic Forest, and the Pampa (GOMPPER, DECKER 1998).

Coatis are gregarious, with the exception of mature males who have solitary habits and only join 
the group during the mating period (EISEMBERG \& REDFORD, 1999). The coati diet is varied, as expected for a species classified as omnivorous (EISEMBERG \& REDFORD, 1999), and includes fruits, arthropods, annelids, and small vertebrates. It is common for coatis to exploit household waste in places where human activity is near, such as in cities or ecological parks, (FERREIRA et al., 2013). According to the literature review, there are no studies on the impact of the ingestion of waste on the health of coatis. Studies on the health of wild coatis have focused on their role as transmitters, vectors, or reservoirs of tropical zoonosis (COSTA et al., 2018; MORAES et al., 2019).

Ingestion of garbage waste by birds and mammals is a common behavior observed around the world, with multifactorial causes and serious consequences for the health of animals, humans, and the environment (KATLAM et al., 2018). The main cause of garbage consumption is the lack of proper packaging and handling of food waste, which allows for visualization or olfactory detection of volatile molecules, which attracts wild animals (KATLAM et al., 2018).

Access to the contents of the dumps is often accompanied by the spreading of waste, increasing the contamination of the environment, the proliferation of insects, and access to synanthropic vectors of zoonosis, such as rats and flies (HIMSWORTH et al., 2013). The consumption of waste can be hazardous to the health of wild animals, leading to contamination by pathogens, ingestion of toxins, and injuries due to corrosive chemical or the mechanical action of fragments of indigestible material (WHO, 2018).

Because it has been demonstrated in the scientific literature that coatis are frequent exploiters of dumps in parks and their surroundings (ALVESCOSTA et al., 2004; FERREIRA et al., 2013), this study investigated their diet in parks that have public visitation. Specifically, the fecal content of coatis was investigated to identify the occurrence of material that makes up their diet and any indigestible residues that originate from the consumption of garbage. The article was complemented with a discussion of how the ingestion of garbage can have adverse consequences for the health of coatis.

\section{METHODS}

This study was carried out in three ecological parks located in the state of Minas Gerais, Brazil (Figure 1): Mangabeiras Municipal Park (PMM), Caparaó National Park (PNC), and Água Limpa Ecological Station (EEAL). During the years studied (2012 and 2013), PMM received 1,336,716

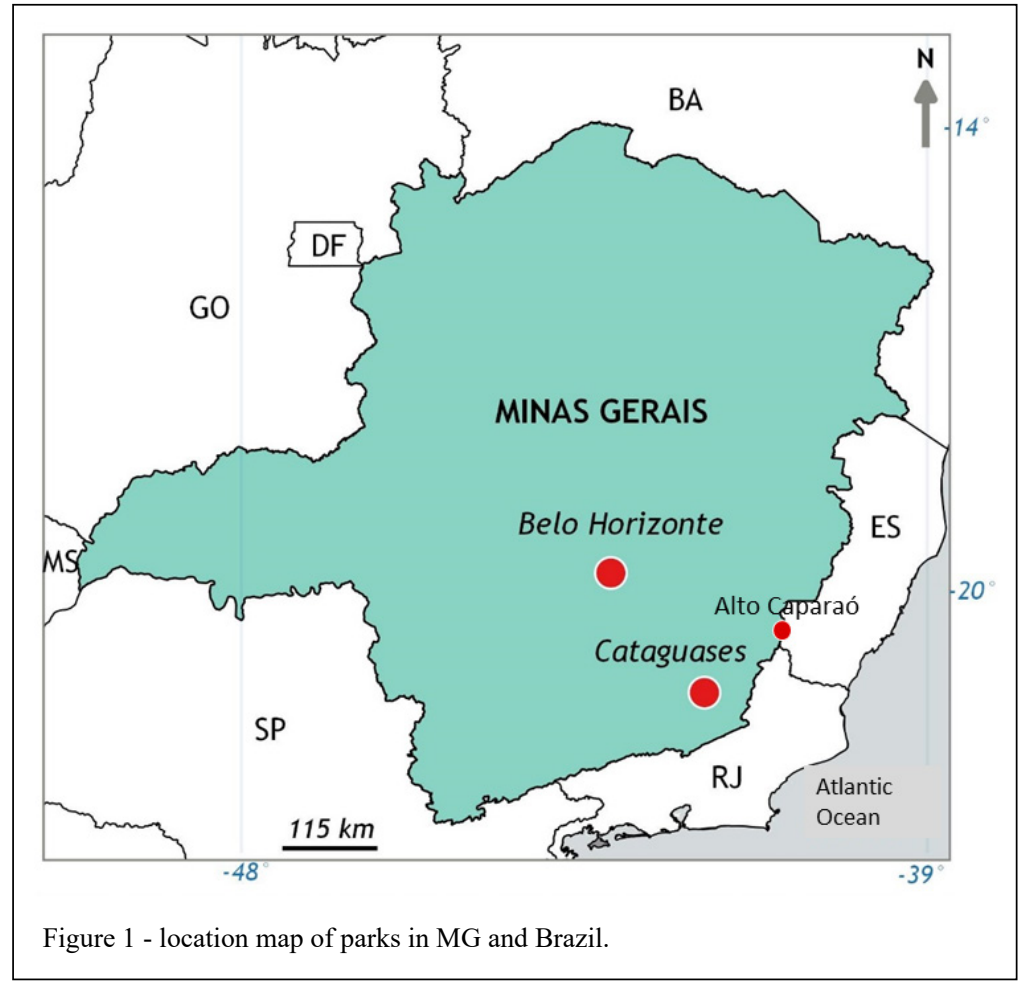

Ciência Rural, v.52, n.2, 2022. 
visitors, while for PNC, an influx of 67,000 visitors was estimated. In the EEAL, the public is not allowed, except for educational school activities or zoo botanical research. In PMM and PNC it is common to observe visitors feeding wild animals or to hear reports from tourists who have had some conflict with coatis, especially due to "theft" of food from backpacks or campers' tents. In PMM, coatis are often observed turning over the bins in the park and there are reports of excursions in dumpsters of nearby houses (personal observations). In PNC, it is also possible to observe the animals exploiting the leftover food deposited in the bins at the camping areas and visitors' rest areas (personal observation).

\section{Parque Nacional do Caparaó}

PNC is located on the border between the states of Minas Gerais and Espírito Santo, between $20^{\circ} 18^{\prime}$ and $20^{\circ} 37^{\prime}$ south latitude and $41^{\circ} 42^{\prime}$ and $41^{\circ} 51^{\prime}$ 'west longitude Greenwich (Oliveira, 2006 apud Ibama, 2006). It was created by Federal Decree No. 50,646 of May 24, 1961. The park currently covers $31,762.93$ hectares, distributed among the municipalities of Alto Caparaó, Caparaó, Espera Feliz, and Alto Jequitibá (MMA, 2015). The park has two rest areas where it is possible to camp, with infrastructure that includes bathrooms, barbecue grills, tables, and benches. At these locations, there are drums with covers in the small parking areas, that are used as trash bins (MMA, 2015; ICMBio, 2017).

\section{Parque Municipal das Mangabeiras}

PMM is located at the northern limit of the "Iron Quadrilateral," in the southern region of Belo

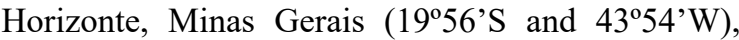
and covers an area of 337 hectares. Part of the park lies in Serra do Curral and is limited by residential areas (Serra, Mangabeiras, and Vila Cafezal neighborhoods) and a private mining area (ROCHA\& ABJAUD, 2012).

PMM serves as a leisure area for the population of Belo Horizonte, with sports areas, a theater arena, kiosks, snack bars, a picnic area, tables, and benches. There are several bins, some with metal lids, where visitors' food waste can be discarded.

\section{Estação Ecológica Água Limpa}

EEAL is located in the municipality of Cataguases $\left(21^{\circ} 22^{\prime} 26^{\prime \prime} \mathrm{S}\right.$ and $\left.42^{\circ} 42^{\prime} 55^{\prime \prime} \mathrm{W}\right)$, in the state of Minas Gerais, covering an area of 70.66 hectares. The predominant vegetation is Semi deciduous Seasonal Forest of the Atlantic Forest, which covers $88 \%$ of the park's area (FORNY, 2008).
In EEAL, there are a botanic vivarium, a soccer field, and a visitors' center with two buildings that occupy approximately $50 \mathrm{~m}^{2}$ each. Recreational visits are not allowed, with the exception of sporadic visits from schools for classes, or researchers who study the EEAL fauna and flora. It is estimated that 9,000 people performed activities at EEAL during the study period (FORNY, 2008).

\section{Data collection and analysis}

Sample collection took place in locations coatis frequented and in which they were often spotted by park employees, with the exception of EEAL, where trails used by the animals were sought. The identification of feces occurred through direct observation or by analysis of material characteristics. A cylindrical shape, having a pasty consistency and an odor of fermented fruits, suggestive of a fruit-rich diet, generally characterizes coati feces (Figure 2). The color can vary from dark brown to yellowish brown or greenish. In most of the collected material, it was possible to observe, without the aid of a magnifying glass, the presence of seeds, fruit shells, exoskeletons, hair, the remains of small vertebrates (scales, egg shells, bones), the remains of packaging, and food from the human diet (rice and corn). During sampling, a change from cylindrical and pasty to a liquid consistency was observed two to three hours after the ingestion of processed foods consumed from the trash.

The samples were collected from May to September of 2012 and from March to September of 2013. There was no collection done from October to February due to the birth of the coati pups and the period of heavy rain. After collection, the samples were stored in universal collectors and identified. During laboratory screening, the samples' volumes were measured, after which they were washed in running water through $4 \mathrm{~mm}, 2 \mathrm{~mm}$, and $1 \mathrm{~mm}$ mesh sieves, placed in Petri dishes, and dried in an oven with a temperature of $25^{\circ} \mathrm{C}$. Subsequently, the samples were screened with the aid of a stereoscopic magnifying glass (40x) and fine-tipped forceps. The items were separated into four main categories (plant material, animal material, garbage, and unidentified material). The plant material was subcategorized into general plant material and seeds. The animal material was sub-categorized into arthropod fragments, pieces of worms, bones, feathers, and scales. Garbage was sub-categorized by its chemical and physical characteristics (paper, string, plastic, latex/rubber, aluminum, and glass). When possible, in order to identify the items sampled at the lowest possible taxonomic level, comparisons were made 


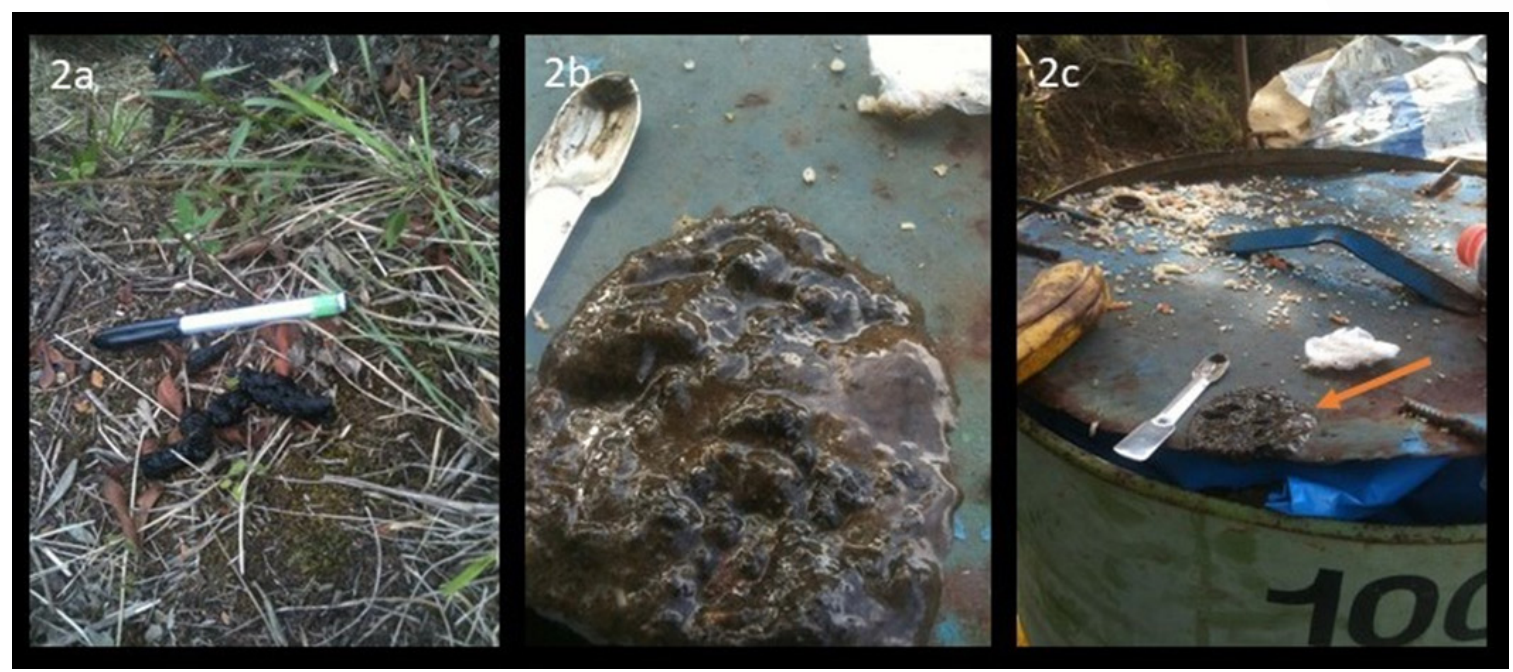

Figure 2 - Coati stool samples collected in PNC during the study. Figure 2a: normal feces collected far from the locations where trash is consumed. Figure 2b: pasty stools on top of a wastebasket made from a metallic barrel. Figure $2 \mathrm{c}$ : the same sample photographed from a more distant perspective, showing the wastebasket and debris.

with samples collected in the study area, materials in collections were consulted, and expert researchers made identifications.

To determine the importance of each item in the stool, the percentage occurrence (PO) of each category was calculated in comparison to the total (MAEHR \& BRANDY, 1986). All procedures were in accordance with ethical and legal precepts and authorized by the Ethics Committee on the Use of Animals at the Federal University of Viçosa (CEUA/ UFV), Process No. 03/2013, and by SISBio/ICMBio $\mathrm{n}^{\mathrm{0}} 31120-2$ and 39017-1.

\section{RESULTS}

Sixty-two samples were analyzed, 22 from PMM, 35 from PNC, and 5 from EEAL. The mean volume and standard deviation of the fecal material analyzed was $16.3 \pm 1.9 \mathrm{~g}$ for PMM, 17.5 $\pm 2.3 \mathrm{~g}$ for PNC, and $16 \pm 2.9 \mathrm{~g}$ for EEAL. In all samples from the three parks, plant material was detected, including leaf fragments, shoots, stamens, stems, flowers, and fruits. Seeds were observed in $36.4 \%$ of PMM samples and $48.6 \%$ of PNC samples; however, none were reported in EEAL samples.

Among material of animal origin, the presence of arthropod fragments (thorax, abdomen, paws, wings or eggs) was detected in $100 \%$ of PNC and EEAL samples. Only $87.3 \%$ of PMM samples contained arthropod fragments. Worms were present in $8.6 \%$ of PNC samples, but none were reported in the feces from PMM or EEAL. Bones were found in $13.6 \%$ and $51.4 \%$ of PMM and PNC samples, respectively. No bones, scales, or bird feathers were reported in EEAL samples. Scales were identified, however, in $9.1 \%$ and $14.3 \%$ of PMM and PNC samples, respectively. Bird feathers were observed in $4.5 \%$ of PMM samples and in $2.9 \%$ of PNC samples.

Fragments of industrialized indigestible matter were detected in 54.5\% of PMM feces, 34.3\% of PNC feces, and $40 \%$ of EEAL feces (Figure 3). The presence of strings was observed in $9.1 \%$ of PMM samples, $14.9 \%$ of PNC samples, and $20 \%$ of EEAL samples. Paper was observed in $50 \%$ of PMM samples, $20 \%$ of PNC samples, and $20 \%$ of EEAL samples. Plastic fragments were identified in $9.1 \%$ of PMM samples and $17.1 \%$ of PNC samples. None were found in EEAL samples. Aluminum fragments were detected in $8.6 \%$ of PNC samples and glass was reported in $4.5 \%$ of PMM samples. Fragments of aluminum and glass were not found in the other samples. Pieces of latex were detected in $13.6 \%$ of PMM samples and in $7.7 \%$ of PNC samples. Latex was not found in EEAL samples.

\section{DISCUSSION}

In general, the results of this study are in alignment with other studies on the feeding ecology 


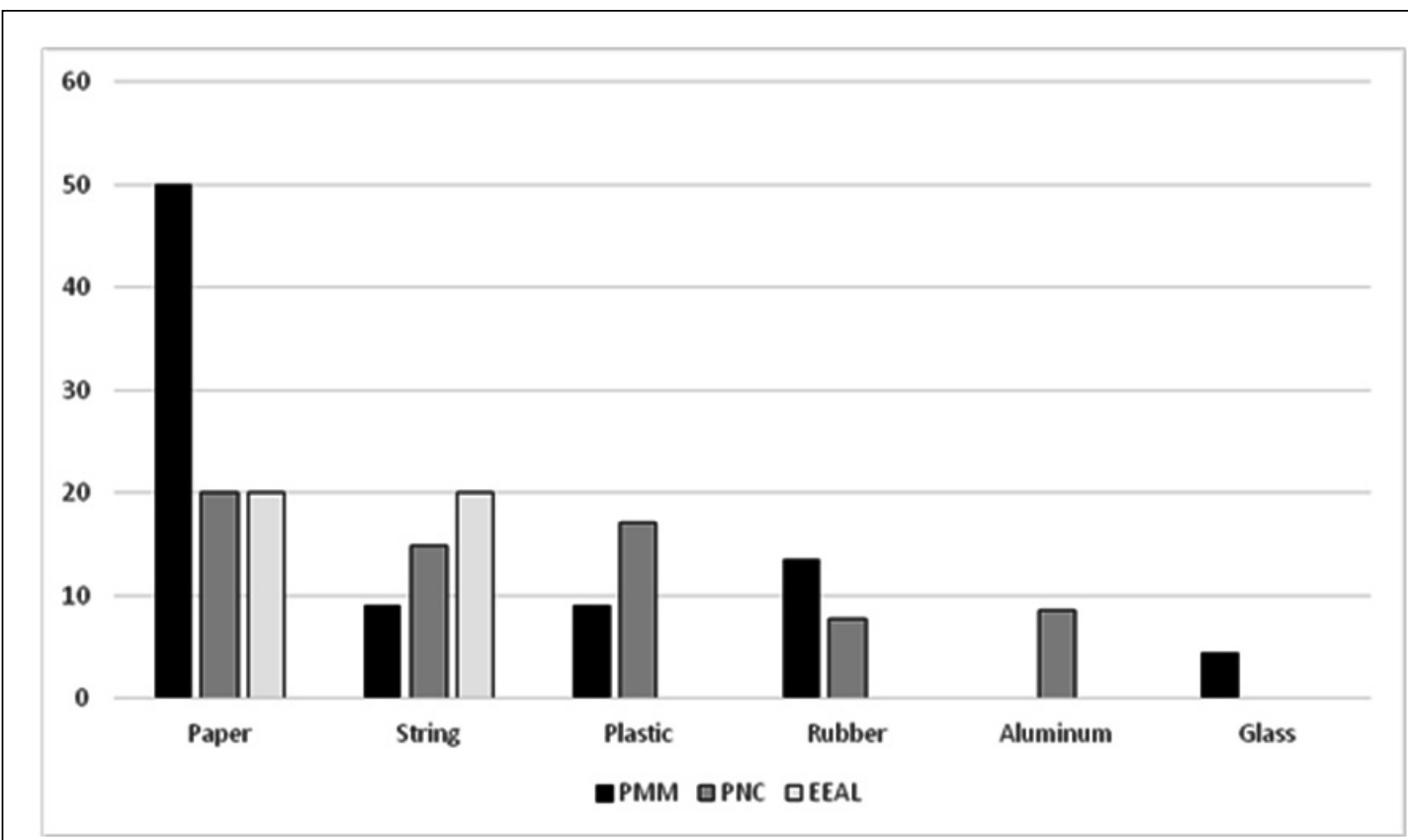

Figure 3 - Percentage (\%, represented by the numbers in the figure) of garbage fragments (paper, string, plastic, rubber/latex, aluminum, and glass) found in the feces of coatis from the three parks (Mangabeira Municipal Park - PMM; National Park Caparaó-PNC; and Estação Ecológica Água Limpa-EEAL). The percentage refers to a binary analysis (occurs or does not occur) of the material identified out of the total number of fecal samples per park.

of coatis, whose recorded diet is based on botanical material and invertebrates (ALVES-COSTA et al., 2004; FERREIRA et al., 2013; HIRSCH, 2009). Botanical material and arthropod fragments were reported in all feces, except PPM samples. As has been reported in other studies, these results characterized coatis as highly opportunistic carnivores that easily adapt to exploit food sources discarded by humans (ALVES-COSTA et al., 2004; FERREIRA et a., 2013). The lack of any trace of arthropods in the feces of some PMM animals may be due to either low intake or complete digestion, though the latter is less likely because the wings and carapaces are highly keratinized and indigestible, being eliminated at the stools. Arthropods are opportunistically found prey, requiring an active search on the part of predatory animals; therefore, their presence in feces depends on the amount ingested and its digestibility (HIRSCH, 2010). Because arthropod fragments are present in most feces, this suggested low intake by some individuals, either due to low availability or due to lower demand for arthropods by the PMM coatis. Even more than simply low availability, the activity spent by coatis searching for food waste in the trash can take away foraging time that would normally be allocated to arthropod predation, optimizing the energy expenditure/intake ratio. This positive balance between cost and benefit is expected with regard to wild animal foraging (KREBS, MCCLEERY, 1984), which is adaptive and seeks to optimize the exploitation of food resources.

The calorie richness of processed foods that are generally consumed by Brazilians (LOUZADA et al., 2015), when present in the waste disposed in the parks' garbage bins, may give surplus energy to coatis that consume them, supplying much of what would ordinarily be supplied by the intake of arthropods. There are no studies on the nutritional requirements of wild or captive coatis, but arthropods supply not only calories, but also a rich amount of lipids (ranging from 10 to $50 \%$ ), amino acids (ranging from 30 to $60 \%$ ) and other micronutrients that can be scarce in the waste consumed in the dumps (HAWKEY et al., 2021). For mammals, amino acids are irreplaceable nutrients that supply the physiological needs for proteins, enzymes, hormones, and immune molecules (PARK, 2006). 
The lack of arthropods in all the feces of coatis from PMM, where there is a high concentration of visitors, can be worrying from a nutritional point of view, if garbage is heavily concentrated in their diets. However, stereoscopy is unable to identify some of the food fragments, and there is highly digestible material that will not be found in feces (MAEHR \& BRANDY, 1986). For this reason, very few worms were reported in the samples, as they are prey composed of soft parts that rarely leave residues in the stool that can be identified. Less digestible, keratinized materials, such as hair, feathers, scales, and bones, can be more easily identified in feces with a stereoscope. The hairs identified in this study were all from coatis, whose ingestion was accidental, due to self- or allogrooming behavior, common for this species (GASCO et al., 2016. The rare presence of feathers suggested that coatis eventually fed on parts of birds, but it cannot be determined whether their habits are those of scavenging or hunting. Snake (Serpentes, Colubridea) and lizard (Lacertoidea, Amphisbaenidae) scales were reported in the samples from two of the parks, but it cannot be determined whether their habits are those of scavenging or hunting. In both PNC and PMM, bones were identified in the stool samples, but the fragments were too small to be able to be identified using a stereoscope. As no hair from other mammal species was found, it is likely that the bones are from the consumption of vertebrates such as snakes, lizards, and birds, whose vestiges were observed in the samples.

In all feces samples, traces of vegetable material were reported, with an emphasis on the presence of seeds, which were often found intact. Ingested seeds are rarely denatured through digestion by omnivorous mammals (SCHUPP et al., 2010), because in the digestive tract, the pulp surrounding the seeds is removed, reducing attack by fungi and competition between seedlings after expulsion in the feces. The digestion process seems to break the dormancy of many seeds, helping them to germinate after being expelled by the animals (SOLTANI et al., 2018). As coatis are able to move for great distances, these findings are in agreement with what has been suggested by other authors, who consider the seed dispersing role of coatis to be a factor in modeling the physiognomy of the regions where they live (ALVES-COSTA et al., 2004). In this way, coatis play an important role in forest dynamics, because their populations can influence the regeneration of these environments (ALVES-COSTA et al., 2004). However, some seeds found in the samples, such as apple and papaya, are considered invasive flora when introduction into a protected area.
The presence of garbage waste in coati feces is a worrying factor, because it has implications for both the health and ecology of the animals. While most studies have focused on plastic intake from trash exploited by birds and aquatic animals (BARNES et al., 2009), little importance has been focused on the diversity of foreign bodies ingested by Neotropical mammals. In this study, paper, string, plastic, latex, metal, and glass fragments were found. Most foreign bodies ingested by animals do not trigger any symptoms (HOBDAY et al., 2014), but when they do occur, there are three ubiquitous clinical signs: pain, bleeding, and constipation. The severity of these symptoms is related to the quantity, shape, and chemical nature of the material ingested (HOBDAY et al., 2014).

Paper and string were the materials most frequently reported in the samples, which are part of common food packaging brought into the park by visitors. There is no estimate regarding what is consumed in the parks, but indirect information can provide an overview for interpreting this data. Estimates by the Brazilian Packaging Association (ABRE, 2020) indicated that $39 \%$ of the packaging industry make use of paper, followed by plastic $(33.8 \%)$, metal $(18.2 \%)$, glass $(7.7 \%)$, and wood $(1.3 \%)$ in 2019 . Therefore, it is expected that a greater presence of paper will be reported in the waste consumed by coatis, who ingest it accidentally. Paper is non-digestible and can potentially cause severe disease, resulting in erosion of the gastric mucosa and obstruction of the intestine (HAYES, 2009). Some paper contains Bisphenol A (BPA), which is a hormone-disrupting substance (MENDUM et al., 2011) that has been reported as cause deficits during brain development in laboratory tests with rodents (WANG et al., 2020).

String is a commonly-found foreign body in marine animals that accidentally ingest fishing lines and nets (BAULCH\& PERRY, 2014), but in coatis it is difficult to explain its origin. The threads found were mostly of some type of nylon, commonly used in packaging fresh vegetables, such as oranges and onions, whose husks were found among the plant material. Accidental ingestion of string from the packaging $t$ seems to be the most likely explanation for the presence of this material in the feces. Interestingly, paper and string were found in the feces of coatis from EEAL, where a few visitors without leisure activity (camping, pic-nics,etc) are allowed, suggesting that this subpopulation of coatis did not access food from visitors origin, but still has access to some source of waste. The northern and 
eastern limits of EEAL border urban areas, and there is a botanic vivarium, located within the park, cared for by employees who spend around eight hours per day on their tasks. Two groups of coatis and three solitary males were found in camera trap images (not shown) in the central region of the park. Even if there are no visitors, it seems that coatis will approach and frequent the area where garbage bins can be found containing food waste discarded by employees.

Plastic material has a ubiquitous presence in scientific reports on the ingestion of garbage by wild animals of various taxonomic levels (NEWSOME\& VAN EEDEN, 2017). In this study, no plastic material was found in the samples from EEAL, probably due to the small sample size (see considerations on this topic below). As expected, and in line with studies in most parts of the world, coatis also were found to have consumed plastics, but at a smaller percentage than either paper or string. Plastic is the second most preferred material used by producers of food packaging in Brazil (ABRE, 2020), so it is expected to appear in a high proportion in garbage waste. Plastic material causes impaction in some animals; however, what is of greatest concern is the accumulation of microplastics in the tissues, which can lead to the appearance of gut microbiota dysbiosis, intestinal barrier dysfunction, and metabolic disorders (LU et al., 2019). These metabolic changes can be expected in coatis that consume waste, but there is nothing reported in the scientific literature. Therefore, the impact of the consumption of plastic and microplastic material on the coati population is currently not known and is a topic that deserves further study.

The ingestion of glass and aluminum can lead to lesions in the oropharyngeal cavity, fractured teeth, and perforating-cutting lesions in the oral mucosa and in the epithelium of the gastrointestinal system (HOBDAY et al., 2014). In some cases, there may be perforation, hemorrhage, or peritonitis, which can be fatal (HOBDAY et al., 2014). In laboratory experiments with animals, it has been shown that aluminum accumulation in the tissues can cause neural degeneration due to chronic inflammatory activation mediated by glial cells (SHAW et al, 2014). Aluminum has been identified as the cause of immune dysfunctions involving the central nervous system (CNS), known as "autoimmune/inflammatory syndrome induced by adjuvants" (ASIA) (reviewed by SHAW et al., 2014). It can be assumed that chronic aluminum intake by coatis may carry a risk of neural damage.

The fragments of soft latex freported in the samples originated from discarded condoms, whose ingestion has clinical consequences that can be classified as mechanical, immunogenic, and infectious. It is estimated that $4.3 \%$ of the human population is allergic to rubber latex (MAHLER, 2020), which contains allergenic proteins. The most common reaction is contact dermatitis mediated by $\operatorname{IgE}$, but there are cases where rubber latex can elicit a hypersensitive immune response in those who are allergic and may lead to death from severe anaphylaxis. It is not only latex that is a potential allergen, but also additives, especially the so called "rubber accelerators" (thiurams, carbamates, thiazoles, and thioureas) and antioxidants (mainly p-phenylenediamine derivatives) that constitute the most frequent contact allergens among the rubber chemicals (MAHLER, 2020).

For animals, a latex allergy has been shown with murine species; however, no natural clinical reactions have been observed in other species (MEADE,\& WOOLHISER, 2002). It is ;therefore, unlikely that coatis will experience a latex allergy. However, mechanical problems such as impaction or transmission of pathogens can occur, though there are few reports in the scientific literature on wild animals that have ingested condoms. In postmortem examinations of emaciated animals (sea turtles, birds, and cetaceans), a high content of foreign bodies, including condoms, was observed, suggesting chronic effects from malnutrition (LAIST, 1997). Other signs observed were perforation or impaction of the digestive system. In these studies, an aggravating factor for malnutrition can be an accumulation of debris consumed by animals in places polluted by garbage (LAIST, 1997; MEE et al., 2007; NEWSOME \& VAN EEDEN, 2017).

There are many diseases that can potentially be transmitted by contact with used condoms and other materials found in the garbage. In an extensive review of the literature on "reverse zoonosis" (diseases transmitted from humans to other animal species), Messenger et al (2014) note that $71 \%$ of pathogen transmission occurs through direct contact, with the remaining $29 \%$ via indirect contact, including fomites. Half of the studies refer reverse zoonosis from humans to wildlife, compared to farm animals or pets (MESSENGER et al, 2014). For example, some severe diseases that are potentially transmissible to wildlife are tuberculosis, salmonellosis, colibacillosis, hepatitis E, metapneumovirus, rotavirus, and giardiasis (MESSENGER et al, 2014). Therefore, the ingestion of used condoms, where semen, vaginal secretions, saliva, and traces of feces can be found, is extremely 
risky to the health of coatis. The ingestion of condoms highlights the potential severity of contact between wild animals and human-generated refuse, with the food that serving as a culture for pathogens, involuntarily preserving them. The percentage of garbage consumed can reach noxiuos levels in the diet of some coatis in all three parks, PMM, PNC, and EEAL. Data was not found in the scientific literature about the morbidity and mortality in coatis caused by garbage, but severe damage to wild animals is recorded in many studies (for example, LAIST, 1997; MEE et al., 2007; NEWSOME \& VAN EEDEN, 2017).

The ingestion of waste from garbage is hazardous and likely to damage the oral and digestive systems, but some paradoxical data has been recorded in the scientific literature. A study of wildlife feeding from dumps on all continents, PLAZA \& LAMBERTUCCI (2017) found a 72.6\% positive impact out of 159 articles, including improvements to body condition, enhanced reproductive performance and abundance, and a higher survival rate. Around one quarter showed negative impacts such as the risk of infection, poisoning, spread of introduced invasive species, and conflicts between humans and animals (PLAZA \& LAMBERTUCCI, 2017). In view of the results presented here, this study lines up on the side of negative impacts, strongly suggesting that the health of some of the coatis is under threat, at risk of physical injuries, infectious diseases, and metabolic disorders.

While clinical changes can be quickly noticed by owners in domestic animals, for wild animals, detection rarely occurs with enough time for treatment. A clinical or surgical intervention in wild animals presents many difficulties that can prevent any curative action. It is known; however, that the presence of foreign bodies in the digestive system can lead to suffering and death (HOBDAY et al., 2014), which is in itself an ethical, moral, and legal problem when caused by recurring human behavior (DELON \& PURVES, 2018). Both professionals and the lay community need to reflect on human conduct in places where there is contact between people and wild animals. From a pragmatic point of view, it should be noted that most of these findings are postmortem (BAULCH \& PERRY, 2014), which should provide incentive to develop eminently preventive and immediate strategies to avoid the ingestion of foreign bodies from the garbage by coatis. The most effective strategy to avoid ingestion is to develop effective barriers that keep wild animals from accessing the garbage and, in parallel, to implement a program for the preservation and expansion of available food sources. The preservation and expansion of protected areas are the most appropriate strategies to guaranteeing the food sources of the animals that make up a given ecosystem, thereby preventing involuntary, unplanned, and invasive food suppression (NEWSOME \& VAN EEDEN, 2017).

The present study has limitation such as the non-presentation of clinical cases related to the ingestion of fragment of garbage in coatis. The emergence of clinical cases with wild mammals in ecological parks depends on a fauna surveillance service (MÖRMER et al., 2002), something that is not common in Brazil. Therefore, the occurrence of cases of ingestion of fragments of garbage depends on randomness and opportunity. In fact, in our review of the literature, we found no articles that absorb the intake of foreign bodies in wild coatis.

\section{CONCLUSION}

This study confirmed the results from other studies that concluded that the coati diet is omnivorous and opportunistic, based mainly on plant material and arthropods. However, fragments of garbage (paper, string, plastic, rubber/latex, aluminum, and glass) were found in the feces of coatis from the three parks. The coatis' contact with waste is ubiquitous, making clear the serious risk to their health in the parks. Some actions are recommended: 1. Increase the environmental education of visitors; 2. Improve the storage and disposal of waste generated in the parks; 3 . Periodically monitor the health of coatis, in order to intervene when possible; 4 . Create a permanent program to study the ecology of the species in the three parks.

\section{ACKNOWLEDGMENTS}

The authors would like to thank the staff of PMM, PNC, and EEAL for the support received during the study. We also thank Coordenação de Aperfeiçoamento de Pessoal de Nível Superior (CAPES) and the Conselho Nacional de Desenvolvimento Científico e Tecnológico (CNPq) for the partial support to graduate students.

DECLARATION OF CONFLICT OF
INTEREST

We have no conflict of interest to declare.

\section{AUTHORS' CONTRIBUTIONS}

All authors contributed equally for the conception and writing of the manuscript. All authors critically revised the manuscript and approved of the final version.

Ciência Rural, v.52, n.2, 2022. 


\section{REFERENCES}

ABRE, 2020. Available from: <https://www.abre.org.br/dados-dosetor/ano2019>. Accessed: Dec. 11, 2020

ALVES-COSTA et al. Variation in the diet of the brown-nosed coati (Nasua nasua) in southeastern Brazil. Journal of Mammalogy, v.85, n.3, p.478-482, 2004. Available from: $<$ https://academic.oup. com/jmammal/article/85/3/478/900974? $\operatorname{login}=$ true $>$. Accessed: Nov. 12, 2020. doi: 10.1644/1383945.

BARNES, D. K. A. et al. Accumulation and fragmentation of plastic debris in global environments. Philosophical Transactions of the Royal Society B. v.364, p.1985-1998, 2009. Available from: $\quad<$ https://royalsocietypublishing.org/doi/abs/10.1098 rstb.2008.0205>. Accessed: Dec, 12, 2020. doi: 10.1098/ rstb.2008.0205.

BAULCH, S.; PERRY C. Evaluating the impacts of marine debris on cetaceans, Marine Pollution Bulletin. v.80 n.1-2, p.210-221, 2014. Available from: <https://www.sciencedirect.com/science/ article/abs/pii/S0025326X13007984>. Accessed: Dec. 12, 2020. doi: 10.1016/j.marpolbul.2013.12.050.

COSTA, G. B. et al. (2018). Vaccinia virus among domestic Dogs and Wild Coatis, Brazil, 2013-2015. Emerging infectious diseases, v.24, n.12,p. 2338-2342. Available from: <https://www. ncbi.nlm.nih.gov/pmc/articles/PMC6256396/pdf/17-1584.pdf>. Accessed: Dec. 23, 2020. Doi:10.3201/eid2412.171584

DELON, N.; PURVES, D. Wild animal suffering is intractable. Journal of Agriculture Environmental Ethics, v.31, p239-260, 2018. Available from: <https://link.springer.com/article/10.1007/ s10806-018-9722-y>. Accessed: Dec. 23, 2020. doi: 0.1007/ s10806-018-9722-y.

EISEMBERG, J. F.; REDFORD, K. H. Mammals of the Neotropics: the Central Neotropics. v.3. Chicago: University of Chicago Press, 1999. 281 p.

FERREIRA, G. A. et al. Diet of the coati Nasua nasua (Carnivora: Procyonidae) in an area of woodland inserted in an urban environment in Brazil. Revista Chilena de História Natural, v.86, p.95-102, 2013. Available from: <https://www.redalyc.org/ pdf/3699/369944184008.pdf >. Accessed: Dec. 23, 2019. doi: 10.4067/S0716-078X2013000100008.

GASCO, A. D. C. et al. Ring-tailed coatis anointing with soap: a new variation of self-medication culture? International Journal of Comparative Psychology, v.29, p.1-11, 2016. Available from: $<$ http://escholarship.org/uc/item/1dq4s4p5>. Accesed: Dec. 19 2020. doi: 10.5070/P4291030113.

GOMPPER ,M. E.; DECKER, D. M. Nasua nasua. Mammalian Species, v. 580, p. 1-9, 1998. Available from: <https://academic oup.com/mspecies/article/doi/10.2307/3504444/2600752>. Accessed: Nov. 20, 2020. doi: 10.2307/3504444.

HAWKEY, K. J. et al. Insects: A potential source of protein and other nutrients for feed and food. Annual Review of Animal Biosciences. v.9, 2021. Available from: <https://www.annualreviews.org/doi/ abs/10.1146/annurev-animal-021419-083930>. Accessed: Mar. 09, 2021. doi: 10.1146/annurev-animal-021419-083930.

HAYES, G. Gastrointestinal foreign bodies in dogs and cats: a retrospective study of 208 cases. Journal of Small Animal Practice, v.50n.11, p.576-83, 2009. Available from: <https://onlinelibrary. wiley.com/doi/abs/10.1111/j.1748-5827.2009.00783.x>. Accessed: Nov. 21, 2020. doi: 10.1111/j.1748-5827.2009.00783.x.

HIMSWORTH, C. G, PARSONS, K. L., JARDINE, C., PATRICK, D. M. Rats, cities, people, and pathogens: a systematic review and narrative synthesis of literature regarding the ecology of ratassociated zoonoses in urban centers. Vector Borne Zoonotic Diseases, v.13, n.6, p.349-59, 2013. Available from: $<$ https://www. liebertpub.com/doi/abs/10.1089/vbz.2012.1195>. Accessed: Jan. 02, 2021. doi: 10.1089/vbz.2012.1195.

HIRSCH, B. T. Tradeoff between travel speed and olfactory food detection in ring-tailed coatis (Nasua nasua). Ethology, v.116, p.671-679, 2010. Available from: <https://onlinelibrary.wiley. com/doi/abs/10.1111/j.1439-0310.2010.01783.x>. Accessed: Dec. 14, 2020. doi: 10.1111/j.1439-0310.2010.01783.x.

HIRSCH, B. T. Seasonal variation in the diet of ring-tailed coatis (Nasua nasua) in Iguazu, Argentina. Journal of Mammalogy, v.90, n.1, p.136-143, 2009. Available from: $<$ https://academic.oup. com/jmammal/article $/ 90 / 1 / 136 / 848758 ? \operatorname{login}=$ true $>$. Accessed: Dec. 14, 2020. Doi:10.1644/08-MAMM-A-050.1.

HOBDAY, M. M. et al. Linear versus non-linear gastrointestinal foreign bodies in 499 dogs: clinical presentation, management and short-term outcome. Journal of Small Animal Practice, v. 55, p. 560-565, 2014. Available from: <https://onlinelibrary.wiley. com/doi/abs/10.1111/jsap.12271>. Accessed: Dec. 14, 2020. doi: $10.1111 /$ jsap. 12271

ICMBio (INSTITUTO CHICO MENDES DE CONSERVAÇÃO DA BIODIVERSIDADE). Guia do visitante. Available from: $<$ http://www.icmbio.gov.br/parnacaparao/guia-do-visitante.html $>$. Accessed: Mar. 28, 2017.

KATLAM, G. et al. Trash on the menu: patterns of animal visitation and foraging behaviour at garbage dumps. Current Science, v.115(12), p.2322-2326, 2018. Available from: <https://www. currentscience.ac.in/cs/Volumes/115/12/2322.pdf $>$. Accessed: Mar. 28, 2019. Doi: 10.18520/cs/v115/i12/2322-2326.

KREBS, J. R.; MCCLEERY, R. H. Optimization in behavioural ecology. In: J. R. KREBS \& DAVIES, N. B. (eds.), Behavioural Ecology: An Evolutionary Approach, p.91-121. Blackwell Scientific Publications, Oxford. 1984.

LAIST, D. W. Impacts of marine debris: entanglement of marine life in marine debris including a comprehensive list of species with entanglement and ingestion records. In Marine debris: sources, impacts and solutions (eds J. M. Coe \& B. D. Rogers), pp.99141. Berlin, Germany: Springer. 1997.

LOUZADA, M. L. C. et al. Alimentos ultraprocessados e perfil nutricional da dieta no Brasil (2008-2009). Revista de Saúde Pública, v.49, p.38-49, 2015. Available from: <https:// www.scielo.br/j/rsp/a/dm9XvfGy88W3WwQGBKrRnXh /?lang=pt $>$. Accessed: Mar. 28, 2019. doi:10.1590/S00348910.2015049006132 .

LU, L. et al. Interaction between microplastics and microorganism as well as gut microbiota: A consideration on environmental animal and human health. Science of the Total Environment, v.667, p.94-100, 2019. Available from: $<$ https://www.sciencedirect.com/ science/article/abs/pii/S0048969719308885>. Accessed: Mar. 28, 2020. doi:10.1016/j.scitotenv.

Ciência Rural, v.52, n.2, 2022. 
MAEHR, D. S.; BRADY, J. R. Food habits of bobcats in Florida. Journal of Mammalogy, v.67, n.1, p.133-138, 1986. Available from: <https://academic.oup.com/jmammal/articleabstract/67/1/133/897943>. Accessed: Mar, 28, 2020. doi: $10.2307 / 1381009$.

MAHLER, V. Allergic Reactions to Rubber Components. In: JOHANSEN, J., et al. (eds) Contact Dermatitis. Springer, Cham. 2020. doi: 10.1007/978-3-319-72451-5 87-1.

MEADE, B. J.; WOOLHISER, M. Murine models for natural rubber latex allergy assessment. Methods, v.27, n.1, p.63-68, 2002. Available from: $<\mathrm{https}: / / \mathrm{www} . s c i e n c e d i r e c t . c o m / s c i e n c e /$ article/abs/pii/S1046202302000531>. Accessed: Mar. 28, 2020. doi: 10.1016/S1046-2023(02)00053-1.

MEE, A. et al. Junk ingestion and nestling mortality in a reintroduced population of California Condors Gymnogyps californianus. Bird Conservation International, v.17, p.119130, 2007. Available from: <https://www.cambridge.org/core/ journals/bird-conservation-international/article/junk-ingestionand-nestling-mortality-in-a-reintroduced-population-of-californiacondors-gymnogyps-californianus/363E14BD4E4068AD8D 9E5E2467905E65>. Accessed: Mar. 28, 2020. doi: 10.1017/ S095927090700069X

MENDUM, T. Concentration of bisphenol A in thermal paper. Green Chemistry Letters and Reviews, v.4, n.1, 81-86, 2011. Available from: <https://www.tandfonline.com/doi/full/10.1 080/17518253.2010.502908>. Accessed: Mar. 28, 2020. doi: 10.1080/17518253.2010.502908.

MESSENGER, A.M. et al. Reverse zoonotic disease transmission (zooanthroponosis): A systematic review of seldom-documented human biological threats to animals. PLoS ONE, v.9, n.2, e89055. 2014. Available from: <https://journals.plos.org/plosone/ article $\mathrm{id}=10.1371 /$ journal.pone. $0089055>$. Accessed: Mar. 20, 2021. doi: 10.1371/journal.pone.0089055.

MMA (MINISTÉRIO DO MEIO AMBIENTE). Plano de Manejo - Parque Nacional do Caparaó. Brasília: MMA/ICMBIO, 2015. Accessed: Dec. 112020

MORAES, M. et al. Parasitological assessment of wild ringtailed coatis (Nasua nasua) from the Brazilian Atlantic rainforest. International Journal for Parasitology. Parasites and Wildlife v.9, p.154-158, 2019. Available from: < https://www.ncbi.nlm.nih. gov/pmc/articles/PMC6527812/>. Accessed: Dec. 11 2020. doi: 10.1016/j.jppaw.2019.04.012.

MÖRNER, T. et al. Surveillance and monitoring of wildlife diseases. Revue Scientifique et Technique International Epizootie. v. 21 , p.67-76. 2002. Available from: <https://citeseerx.ist.psu.edu/ viewdoc/download?doi $=10.1 .1 .1077 .7253 \&$ rep $=$ rep $1 \&$ type $=p$ df/>. Accessed: Dec. 12, 2020. doi: 10.20506/rst.21.1.1321.
NEWSOME, T. M.; VAN EEDEN, L. M. Food waste is still an underappreciated threat to wildlife. Animal Conservation, v.20, p.405-406, 2017. Available from: <https://www.researchgate. net/profile/Lily-Van-Eeden/publication/320519562_Food waste is still an underappreciated threat to wildlife $/$ links/59ec688d0f7e9bfdeb705e $84 /$ Food-waste-is-still-anunderappreciated-threat-to-wildlife.pdf $>$. Accesed: Nov. 11, 2020. doi: $10.1111 /$ acv.12373.

PARK, B. Amino acid imbalance-biochemical mechanism and nutritional aspects, Animal Biosciences, v.19, n.9, p.1361-1368, 2006. Available from: <https://www.koreascience.or.kr/article/ JAKO200628066507619.page>. Accessed: Nov. 21, 2020. doi: 10.5713/ajas.2006.1361.

PLAZA, P. I.; LAMBERTUCCIS.A. How are garbage dumps impacting vertebrate demography, health, and conservation? Global Ecology and Conservation, v.12, p.9-20, 2017. Available from: $<$ https://www. sciencedirect.com/science/article/pii/S2351989417301257>. Accessed: Nov. 27, 2020. doi: 10.1016/j.gecco.2017.08.002

ROCHA, E. A.; ABJAUD, T. T. A metropolização de Belo Horizonte e sua relação com as áreas verdes e o turismo: Parque da Mangabeiras vs. Praça Sete. Observatório Inovacão Turismo, v.7, n.3, p.63-85, 2012. Available from: <http://bibliotecadigital. fgv.br/ojs/index.php/oit/article/view/7874>. Accessed: Apr. 01 2020. doi: 10.12660/oit.v7n3.7874.

SCHUPP, E. W. et al. Seed dispersal effectiveness revisited: a conceptual review. New Phytologist, v.188,p.333-353,2010.Available from: $<$ https:// nph.onlinelibrary.wiley.com/doi/10.1111/j.1469-8137.2010.03402.x>. Accessed: Apr. 01 2020. doi:10.1111/j.1469-8137.2010.03402.x.

SHAW, C. A. et al. Aluminum-induced entropy in biological systems: implications for neurological disease. Journal of Toxicology, v.2014, 27 p.2014. Available from: <https://www. hindawi.com/journals/jt/2014/491316/>. Accessed: May, 142020. doi: $10.1155 / 2014 / 491316$.

SOLTANI, E. et al. A meta-analysis of the effects of frugivory (endozoochory) on seed germination: role of seed size and kind of dormancy. Plant Ecology, v.219, p.1283-1294, 2018. Available from: < https://link.springer.com/article/10.1007/s11258-018-08783>. Accessed: Dec. 10, 2020. doi: 10.1007/s11258-018-0878-3.

WANG, Z. et al. Fetal Bisphenol-A induced changes in murine behavior and brain gene expression persist in aged offspring. Endocrinology, v.161, n.12, bqaa164, 2020. Available from: <https://academic.oup. com/endo/article/161/12/bqaa164/5905560?login=true $>$. Accessed: Dec. 10, 2020. doi: 10.1210/endocr/bqaa164.

WHO (WORLD HEALTH OGANIZATION), 2018. Available from: $<$ https://www.who.int/news-room/fact-sheets/detail/healthcare-waste>. Accessed: Jan. 10, 2021. 